\title{
Mineral analysis in rocks using XRD and Petrography
}

\author{
Muhamad Ragil Setiawan ${ }^{1}$, Mochamad Iqbal ${ }^{2}$, Rahmat Nawi Siregar ${ }^{1}$ \\ ${ }^{1}$ Physics Department, Institut Teknologi Sumatera, Lampung Selatan, Lampung. \\ ${ }^{2}$ Geological Engineering Department, Institut Teknologi Sumatera, Lampung Selatan, Lampung.
}

\begin{abstract}
Rock formation in a region is influenced by many factors such as tectonic and volcanic systems of the area. Both activities will affect the microstructure of the rock. This study analyzes mineral composition in three different rocks. We display the digital image that obtained from XRD and petrography. Rock samples were taken from some formations around Lampung. The analysis was performed on three different rocks: granite, andesite, and schist using XRD and petrography. The granite-R1 sample shows the result of mineral content present in the rock that is quartz, alkali feldspar, plagioclase, biotite. The andesite-R2 sample consists of plagioclase, orthopyroxene, biotite, and volcanic glass. The Schist-R3 sample consist of quartz, muscovite, calcite.
\end{abstract}

\section{Introduction}

The characteristics of rocks has been investigated with various methods ${ }^{[1],[2],[3]}$ in micro structure as well as macro structure which can describe the physical properties of rocks ${ }^{[4],[5]}$. The physical properties such as resistivity can be used as a tool in identifying the reservoir of groundwater. Moreover, the information about permeability, porosity and mineral of rocks will provide the properties of rocks.

One of the most important tool to find the properties of rocks is by applying the electromagnetic wave in describing the subsurface condition. The electromagnetic wave can be generated in some frequencies by using the active or passive method. Ground Penetrating Radar is one of electromagnetic active method by using radar frequency in $1-1000 \mathrm{MHz}$. This method is well known for high resolution shallow subsurface exploration. Micro wave frequencies $(300 \mathrm{MHz}-300 \mathrm{GHz})$ as one of the spectrum of electromagnetic waves, hasn't been widely used in studying the properties of rocks. Thus, We would like to conduct a research in applying the microwave for studying physical properties of rocks.

Meanwhile, the preliminary research has to be carried out before applying microwave method. Before finding the physical properties, the petrography and x-ray analysis need to be consider in classifying the mineral contens of rock.

\section{Material and methods}

\section{Material}

The research has been carried out by analyzing 3 fresh rock sample from some formations in Lampung. We classified the samples based on megascopic and microscopic to find the description of mineral contents. The R1, R2 and R3 samples information are clearly described in Table 1 below. 
ICOSITER 2018 Proceeding

Journal of Science and Applicative Technology

Table 1. Megascopic description of the samples.

\begin{tabular}{ccl}
\hline Sampel Code & Type of rock & \multicolumn{1}{c}{ Megascopic description } \\
\hline R1 & Granite & $\begin{array}{l}\text { Igneous rock, white redish, phaneric, equigranular, } \\
\text { consist of quartz, potassium feldspar, biotite, and } \\
\text { plagioclase. }\end{array}$ \\
& Igneous rock, dark grey, porphiritic, inequigranular, \\
& Andesite & $\begin{array}{l}\text { phenocryst consist of plagioclase, hornblend, the } \\
\text { R2 }\end{array}$ \\
& groundmass is mafic mineral. \\
& Metamorphic rock, dark grey, schistose foliation, \\
& heteroblastic (lepidoblastic and granoblastic), consist \\
& of quartz, calcite, and clay mineral.
\end{tabular}

\section{Methods}

We investigated mineral contents of samples by applying petrography analysis. Petrography analysis is qualitative analysis by slicing the samples into some thin sections which will be observed under polarization microscope. The slicing of samples was carried out in Workshop Obsidian Bandung, whereas petrography analysis was in PTBGN BATAN Jakarta. In order to support the petrography analysis, we applied X-Ray Diffraction (XRD) Method in Laboratorium of Teknik Pertambangan Institut Teknologi Bandung (ITB). The concept of XRD Method is by calculating the diffraction angle of material which is beamed by X-ray transmission. This method can provide the exact mineral information of samples quantitatively.

\section{Result and discussions}

The petrography analysis of samples as main result of this research will be presented in this chapter, whereas XRD method is carried out to support petrography analysis.

R1 Granite (Figure 1) is described as plutonic igneous rock, with fanerik inequigranular texture, holokristalin, crystal size 0,04-5,5 mm, dominan in $3 \mathrm{~mm}$, euhedral-subhedral, primary mineral (97\%) consist of $20 \%$ quartz (D8), $40 \%$ alkali feldspar (B2), 20\% plagioclas (H6) with dominan composition oligoclas (An18-Ab82), 7\% biotit (B7), dan 5\% opak mineral (J6), secondary mineral(4\%) consist of quartz kuarsa and serisit. 

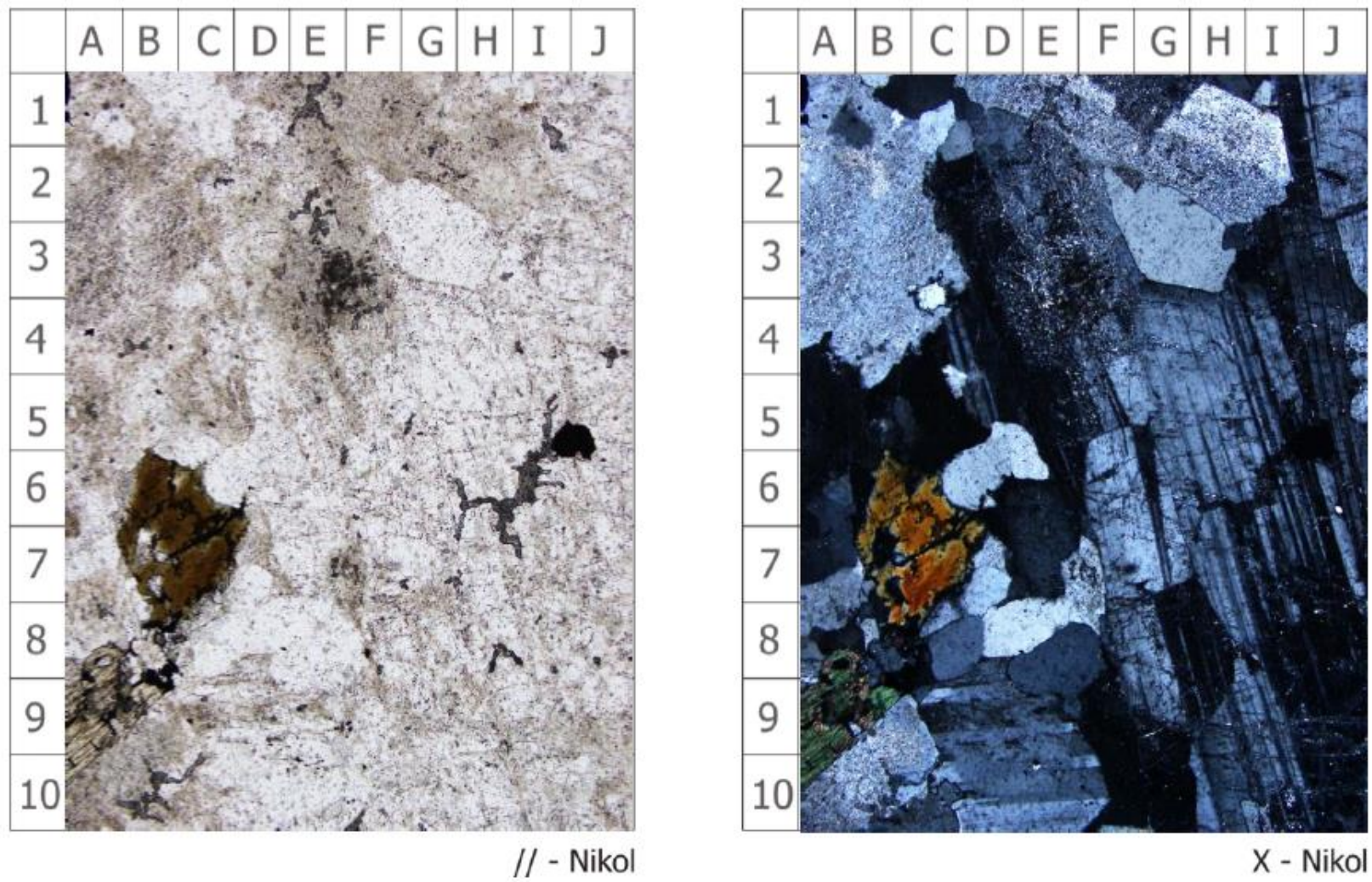

Figure 1. Thin section of R1 granite.

The XRD analysis of R1 (Figure 2) shows that sample contains quartz, labradorite (plagioclas group), kfeldspar, dan cobalt iron. Cobalt iron is not a primary mineral which is formed in rock, so this mineral can be neglected. 
ICOSITER 2018 Proceeding

Journal of Science and Applicative Technology

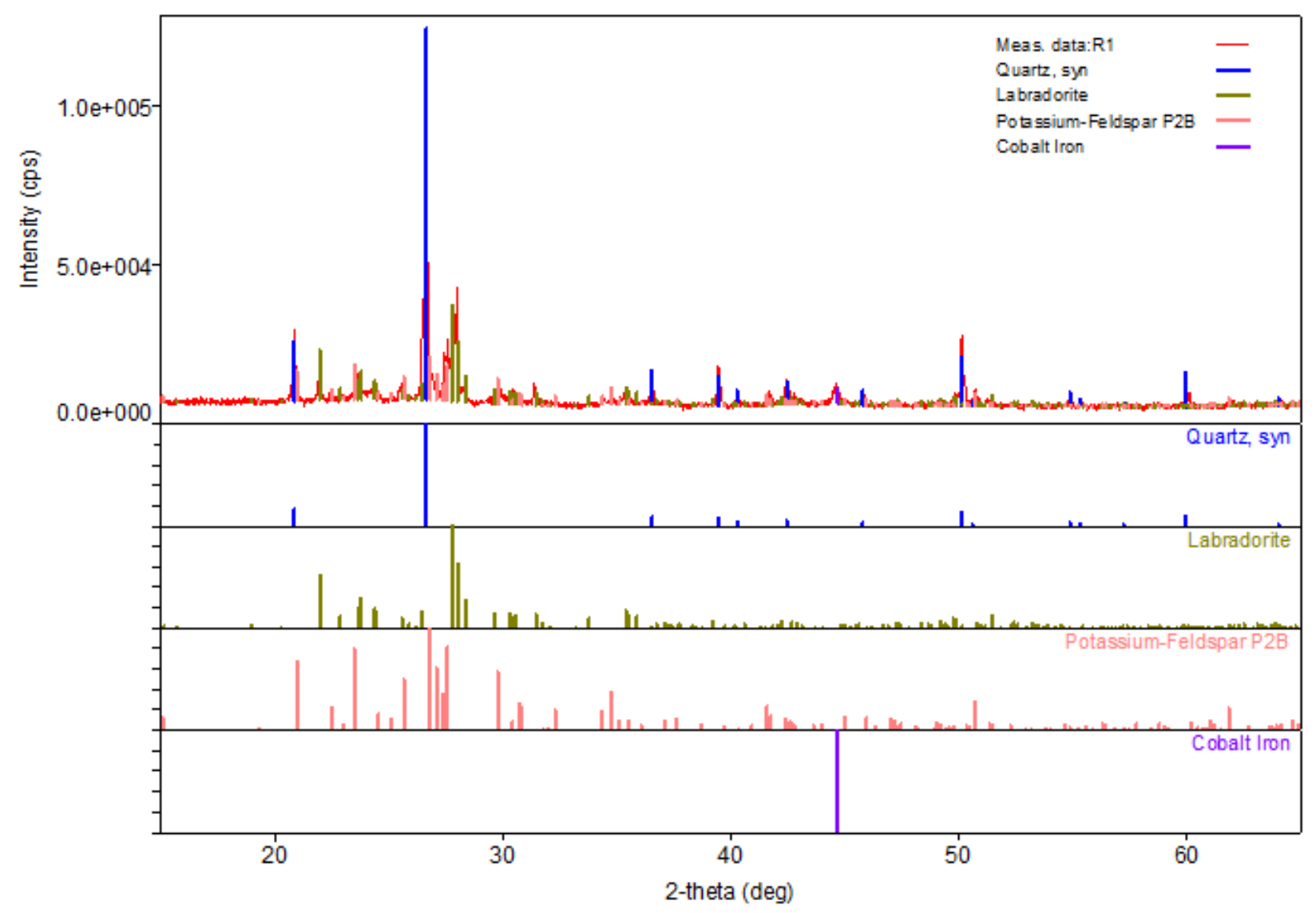

Figure 2. XRD result of R1 granite sample. The result shows that the rock has quartz, labradorite, and kfeldspar content.

R2 andesite (Figure 3), is investigated as volcanic igneous rock, bertekstur porfiritik, hipocristalin, inequigranular, subhedral - euhedral, dominan subhedral, fenokris consist of $10 \%$ plagioclas $(\mathrm{H} 2), 10 \%$ hornblend (E2), 3\% ortopiroksen (I8), dan 5\% mineral opak (D7), 2\% biotit (F1), ukuran kristal $0.02-4$ $\mathrm{mm}$, dominan pada ukuran $1 \mathrm{~mm}$, masadasar with volcanic glass (35\%) dan microlit plagioklas (23\%) which shows flow structure, vesicular $(2 \%)$ with oxide mineral around. 
ICOSITER 2018 Proceeding Journal of Science and Applicative Technology
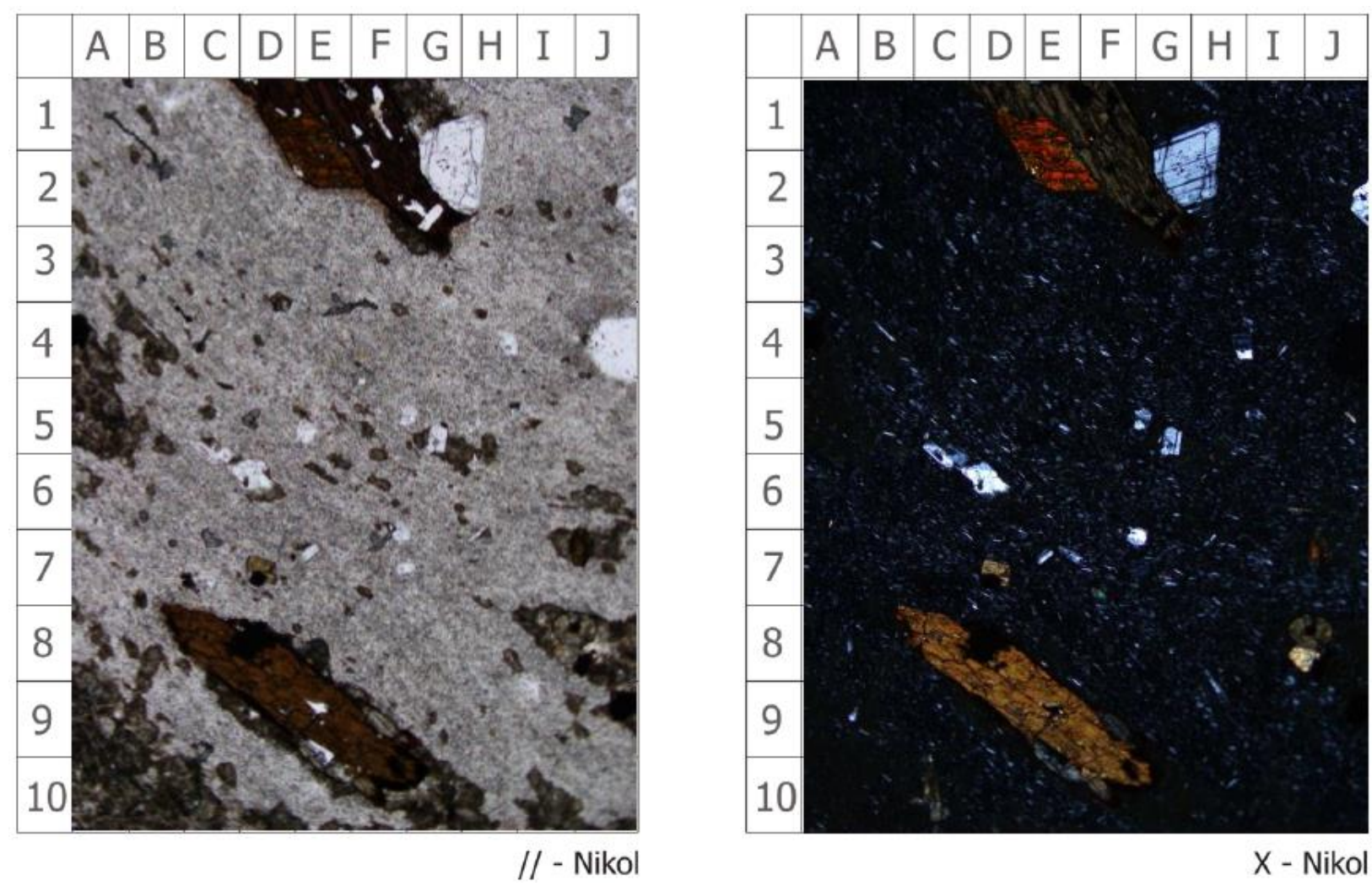

X - Nikol

Figure 3. Thin section of R2 andesite.

The result of R2 XRD (Figure 4) shows that sample contains quartz, andesine (plagioclase group) and coesite (polymorph quartz). 
ICOSITER 2018 Proceeding

Journal of Science and Applicative Technology

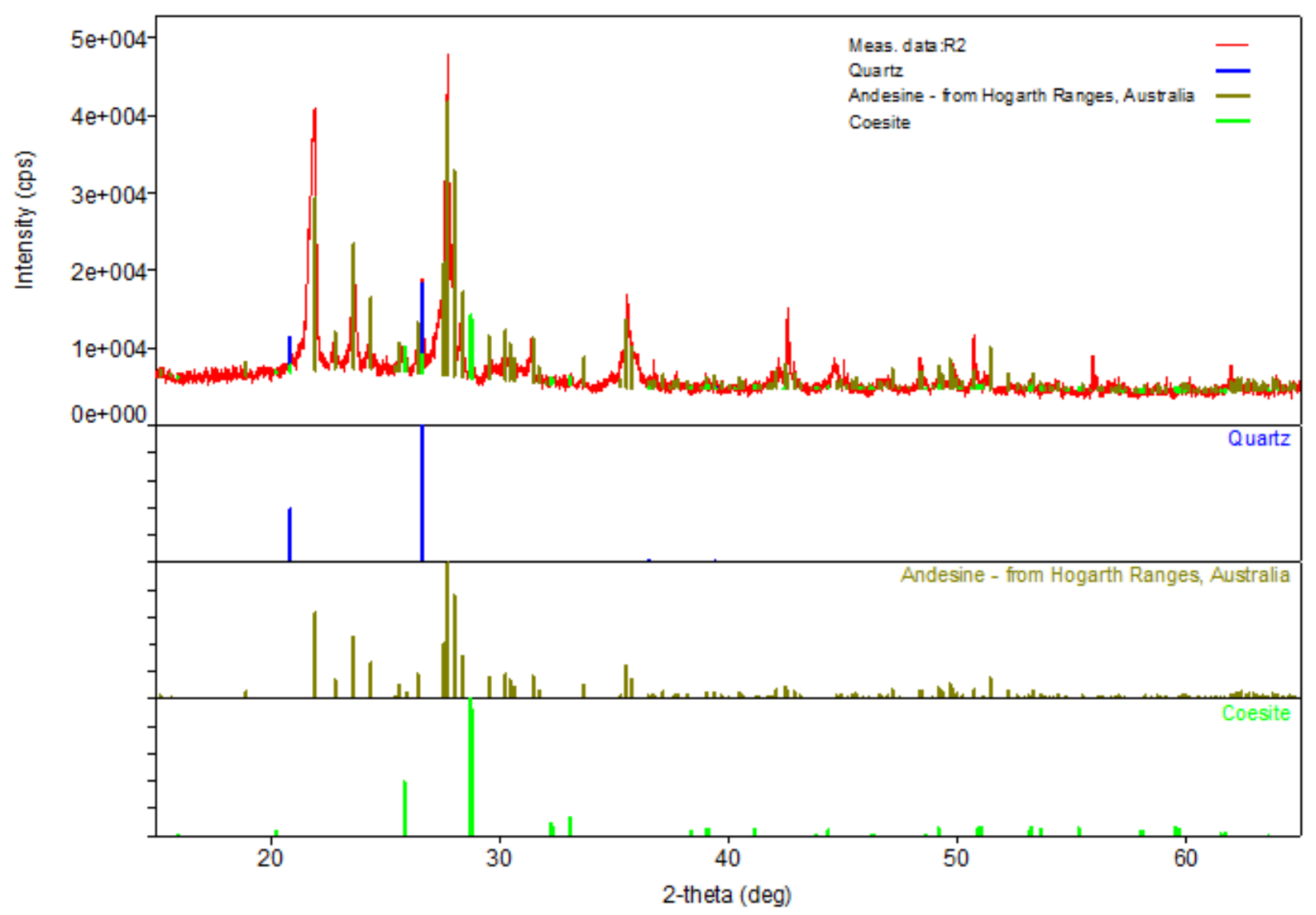

Figure 4. XRD result of R2 andesite sample. The result shows that the rock has quartz, andesine, and coesite content.

R3 Schist (Figure 5), is investigated as metamorf, inequigranular, granoblastic dan lepidoblastik texture, consist of $50 \%$ quartz as granoblastic mineral with crystal elongate texture, $15 \%$ muscovit presence as lepidoblastik mineral, 15\% kalsit (J7) presence as granoblastik mineral dan the crack filling, , 10\% opak mineral, $5 \%$ clay mineral, $3 \%$ oxide mineral with anhedral size from 0.2 to $1.8 \mathrm{~mm}$. 
ICOSITER 2018 Proceeding

Journal of Science and Applicative Technology
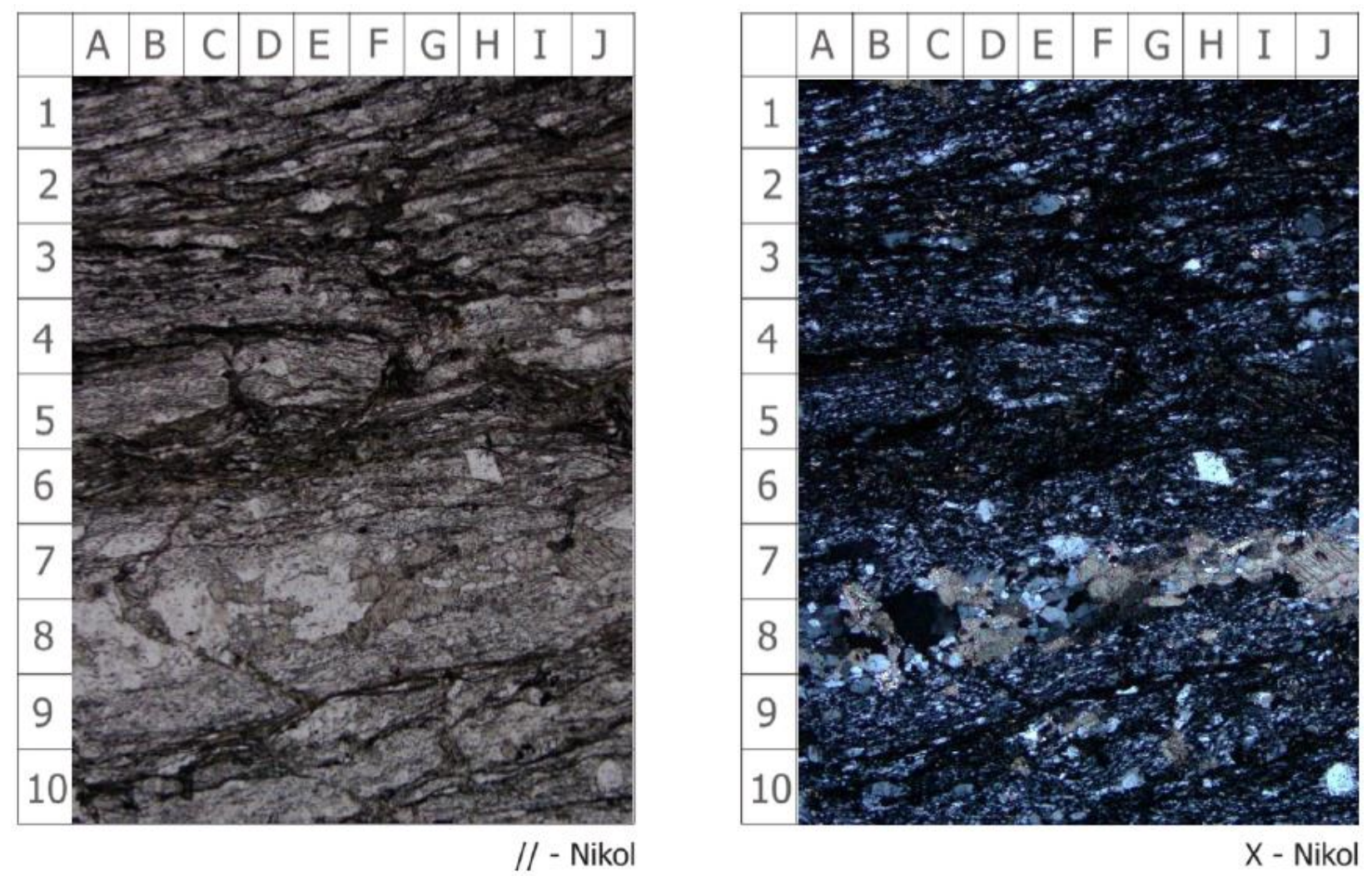

Figure 5. Thin section of R3 schist.

The XRD result of R3 (Figure 6) shows that sample contains quartz, albit (plagioklas group), dan clinochlore (chlorite group). Clinochlore is a chlorite group which present as clay mineral in this rock. 
ICOSITER 2018 Proceeding

Journal of Science and Applicative Technology

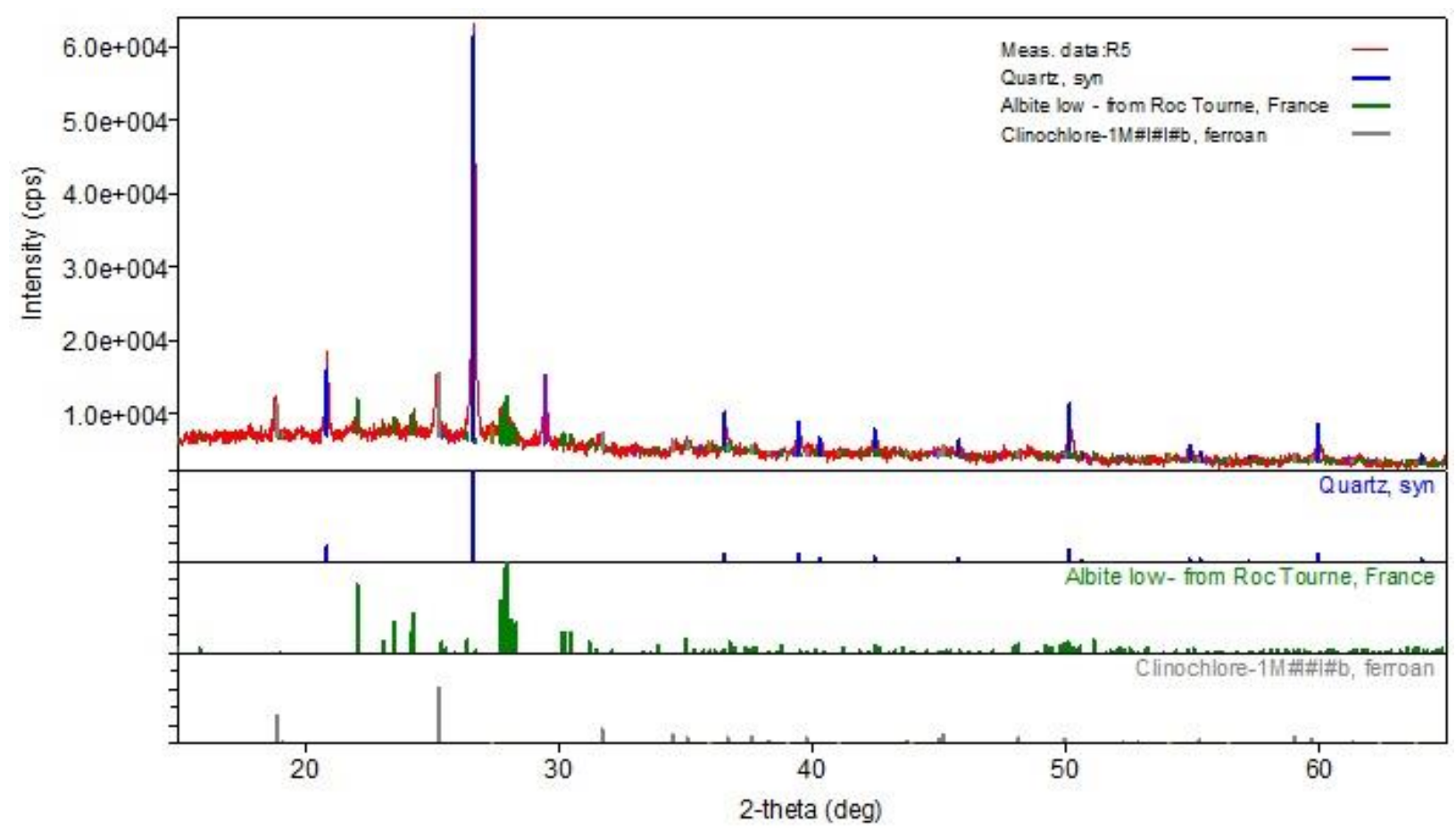

Figure 6. XRD result of R3 schist sample. The result shows that the rock has quartz, albite, and clinochlore content.

\section{Conclusion}

R1 granite sample is a plutonic igneous rock that consist of quartz, alkali feldspar, biotite, plagioclase, sericite. R2 andesite sample is a volcanic igneous rock that consist of plagioclase, hornblend, ortopyroxene, biotite, and a little of quartz as a minor mineral. R3 schist sample is a metamorphic rock that consist of quartz, muscovite, calcite, oxide minerals, and clay mineral (clinochlore is identified).

\section{Acknowledgment}

The authors would like to thanks Institut Teknologi Sumatera for funding this research so the research can be done very well.

\section{References}

[1] Rahman, T., Maxim, L., Yihuai, Z., Ahmed, B., Stefan, I., 2017, Influence of rock microstructure on its electrical properties: an analysis using X-ray microcomputed tomography, Energy Procedia, v. 114 , p. 5023-5031. 
ICOSITER 2018 Proceeding

Journal of Science and Applicative Technology

[2] Ahmed, Z.A., Maxim, L., Sarah, J.V., Michael, L.J., Ahmed, B., Stefan, I., 2015, Pore-scale analysis of formation damage in Bentheimer sandstone with in-situ NMR and micro-computed tomography experiments, Journal of Petroleum Science and Engineering, v. 129. P. 48-57.

[3] Zandomeneghi, D., Voltolini, M., Mancini, L., Brun, F., Dreossi, D., Polacci, M., 2010, Quantitative analysis of $\mathrm{x}$-ray microtomography images of geomaterials: Application to volcanic rocks, Geosphere, v. 6, no. 6, p.793-804.

[4] Arif, M., Ahmed, B., Maxim, L., Stefan, I., 2017, Impact of solid surface energy on ettability of $\mathrm{CO}_{2} /$ brine/mineral systems as a function of pressure, temperature and salinity, Energy Procedia, v. 114, p. 4832-4842.

[5] Rahman, T., Maxim, L., Ahmed, B., Stefan, I., 2016, Residual trapping of supercritical $\mathrm{CO}_{2}$ in oilwet sandstone, Journal of Colloid and Interface, v. 469, p. 63-68. 